\title{
USE OF MULTISPECTRAL IMAGING IN THE EVALUATION OF BURNINGS AND FOREST FIRES IN KRAHÔLANDIA INDIGENOUS LAND (2003-2014)
}

\author{
Lawrence Nóbrega de Oliveira ${ }^{1}$, Gustavo Maximiano Junqueira Lazzarini ${ }^{2}$, Antonio Carlos Batista ${ }^{3}$, \\ Kaio Cesar Cardoso de Lima Fonseca Alves ${ }^{1}$, Marcos Giongo ${ }^{1 *}$ \\ ${ }^{1}$ Universidade Federal do Tocantins, Gurupi, Tocantins, Brasil - eng.lawrencenobrega @ gmail.com; kcclfa @ hotmail.com; \\ *giongo@uft.edu.br \\ ${ }^{2}$ Instituto Brasileiro de Meio Ambiente e Recursos Naturais Renováveis, Gurupi, Tocantins, Brasil - gmjlazzarini@ bol.com.br \\ ${ }^{3}$ Universidade Federal do Paraná, Curitiba, Paraná, Brasil - batistaufpr@gmail.com
}

Received for publication: 02/03/2015 - Accepted for publication: 17/08/2015

\begin{abstract}
Human actions change the natural occurrences of wildfire. The indigenous communities, during their time of occupation of the Cerrado, probably utilized fire to manipulate the landscape and its resources. In this study, we mapped and analyzed the spatial distribution of burned areas of the Kraholândia Indigenous Land, from 2003 to 2014, using Remote Sensing resources and GIS tools. During the assessed period, the total burned area extended across 1,516,873 ha, representing 4.94 times the sum of Kraholândia Indigenous Land area (306,871 ha). The average annual burned area was 126,406 ha $(41.19 \%)$, with the year of the largest burned area recorded at 185,297 ha $(60.4 \%)$ and the year of the smallest burned area was 71,764 ha $(23.4 \%)$. There were 29,764 ha $(9.7 \%)$ that had never been burned during the 12 years, and 1,693 ha $(0.6 \%)$ that had been burned every year of the period. Moreover, the areas that recorded the highest frequency of fire occurrence and burnings were surprisingly not those that produced the largest burned areas over the period. The remote sensing data, allied with methodology employed, succeeded in identifying the frequency of burnings and wildfire in the Krahôlandia Indigenous Land.
\end{abstract}

Keywords: Cerrado; Fire recurrence.

\section{Resumo}

Utilização de imagens multispectrais na avaliação das ocorrências de queimadas e incêndios florestais na Terra Indígena Krahôlandia (2003-2014). As ações humanas alteram as ocorrências naturais dos incêndios e queimadas. Os povos indígenas, quando da ocupação do Cerrado, provavelmente usavam o fogo para manipular a paisagem e os seus recursos em várias épocas do ano. Este trabalho teve por objetivo analisar e mapear a distribuição espacial de áreas queimadas na Terra Indígena Krahôlandia, no período de 2003 a 2014, utilizando ferramentas de sensoriamento remoto e SIG. Nos 12 anos avaliados, a área queimada total foi de 1.516.872,51 ha, que representa 4,94 vezes a área total da TI Krahôlandia (306.871,02 ha). A média anual de área queimada foi de 126.406,04 ha $(41,19 \%)$ com o ano da maior área queimada com 185,297 ha $(60,4 \%)$ e o ano da área menor com 71,764 ha $(23,4 \%)$. Houve 29.764 ha $(9,7 \%)$ que nunca tinham sido queimadas durante os 12 anos, e 1.693 ha $(0,6 \%)$ que tinham sido queimados todos os doze anos. Além disso, as áreas que registraram a maior frequência de ocorrência de incêndios e queimadas não foram surpreendentemente aquelas que produziram as maiores áreas queimadas ao longo do período. Os dados de sensoriamento remoto aliados com metodologia empregada conseguiu identificar a frequência de ocorrência de queimadas e incêndios florestais na terra indígena Krahôlandia.

Palavras-chave: Cerrado; recorrência de fogo.

\section{INTRODUCTION}

Brazilian ecosystems, in almost all their extension (except Caatinga), are classified as dependent/influenced by fire, like Cerrado, Pantanal and Pampas, or as sensible to fire, like Amazonas and Atlantic Rainforest (HARDESTY et al., 2005).

FLORESTA, Curitiba, PR, v. 45, n. 4, p. 853 - 864, out. / dez. 2015.

Oliveira, L. N. de. et al.

ISSN eletrônico 1982-4688 / ISSN impresso 0015-3826 
Cerrado is the second largest Brazilian biome, with an approximate area of 204.7 million of hectares (SANO et al., 2010). Factors like seasonal rainfall pattern, soils poor of nutrients and forest fires occurrences (MIRANDA et al., 2010), determine its dynamics. Burnings occurrence is common in Cerrado, mainly in the dry season, because the herbaceous vegetation becomes dry and very flammable (RAMOS-NETO; PIVELLO, 2000). Human actions change the natural fire occurrence (MIRANDA et $a l ., 2002)$, which start to develop in different regimes and to vary in severity, dimensions, seasonality and frequency, among others (CHUVIECO et al., 2008).

The great majority of fires originates from anthropic activities, where fire is a tool for cleaning and promotion of pastures regrowth, removal of native vegetation and agriculture management (PIVELLO, 2011). Loss of control in these practices originates wildfires, which may also derive from criminal practices.

Indigenous populations occupied Cerrado between 35.000 and 15.000 years ago (LAVALLÉE, 2000). Indigenous communities are mainly hunters and gatherers, which use fire as an instrument to increase production (RAMBO, 2014). There are reports of fire use for hunting, vegetation management, among other activities; and to reduce the flammable material in order to avoid fires of greater proportions (FALEIRO, 2011; MISTRY et al., 2005).

Impacts of these burnings with indigenous activities origin must be monitored. Evaluations in areas more susceptible to forest fires should be conducted, in order to avoid loss of biodiversity in locations where fire has anthropic origins (LAZZARINI et al., 2012). Policies involving constant and continuous monitoring of flora and fauna must be stimulated to elaborate management actions aimed to protect the Cerrado biome (RAMOS-NETO; PIVELLO, 2000). Survey of fire occurrence and distribution of burned areas are between the possible techniques to subsidize these actions (CHUVIECO et al., 2008).

Geo-technologies are promising instruments allowing knowledge improvement of the territory, and contribute to improve its monitoring, planning and management. A Geographic Information System (GIS) is an efficient instrument for analysis of forest fires spatial distribution (VETTORAZZI; FERRAZ, 1998). Remote sensing instruments have a considerable potential for mapping of burned areas and fires regimes, particularly on a regional level. This technology is useful, compared to other conventional approaches, because of its precision, replicability, fast data acquisition, easy database management and practical combination with other thematic databases. Satellite mapping of burned areas is performed by different sensors (different time and space resolutions) and classification procedures.

The present work aimed to map and analyze the spatial distribution of burned areas in Krahôlandia Indigenous Land, in the period from 2003 to 2014, using remote sensing devices and |GIS. Relation between burned area and hotspots was assessed, including dimensioning of the area annually affected by fires, identification of occurrences and the most relevant frequency patterns of burnings and forest fires in the indigenous land.

\section{MATERIAL AND METHODS}

\section{Study area}

The Krahôlandia Indigenous Land (TI Krahôlandia) is located in northwest of the state of Tocantins, approximately $100 \mathrm{~km}$ from the capital, Palmas. This area includes the municipalities of Goiatins and Itacajá, between latitudes $07^{\circ} 50^{\prime} \mathrm{S}-08^{\circ} 50^{\prime} \mathrm{S}$ and longitudes $47^{\circ} 05^{\prime} \mathrm{W}-47^{\circ} 50^{\prime} \mathrm{W}$ (Figure 1).

Established in 1990 by the Decree $\mathrm{n}^{\circ}$ 99.062, the TI Krahôlandia occupies an area of about 3.608 $\mathrm{km}^{2}$ and is home to a population of around 2000 people, distributed in 16 villages of different sizes. Climate of the region is classified as B1wA - humid with moderate water deficiency in winter, according to the climate classification system by Tornthwaite. Climate is distinctly seasonal, characterized by a rainy season starting in October and ending in April. The annual average rainfall varies between 1,600 and $1,800 \mathrm{~mm}$, with approximately $75 \%$ of rainfall concentrated in the rainy season. After the rainy season comes a dry season, with intense burning occurrences, which normally starts in May and extends until September (MISTRY et al., 2005).

According with the survey on soil use and vegetal coverage performed by SEPLAN (Secretaria de Planejamento e da Modernização da Gestão Pública do Estado do Tocantins) for the year 2007, 2\% of the TI Kraolândia area was used for farming, with the remaining area occupied by forest formations, 
savannas and fields. Between others, the principal phyto-physiognomies are Cerrado Strictu Sensu (50\%), Riparian and Gallery Forest (21\%) and Fields (20.6\%) (TOCANTINS, 2012).
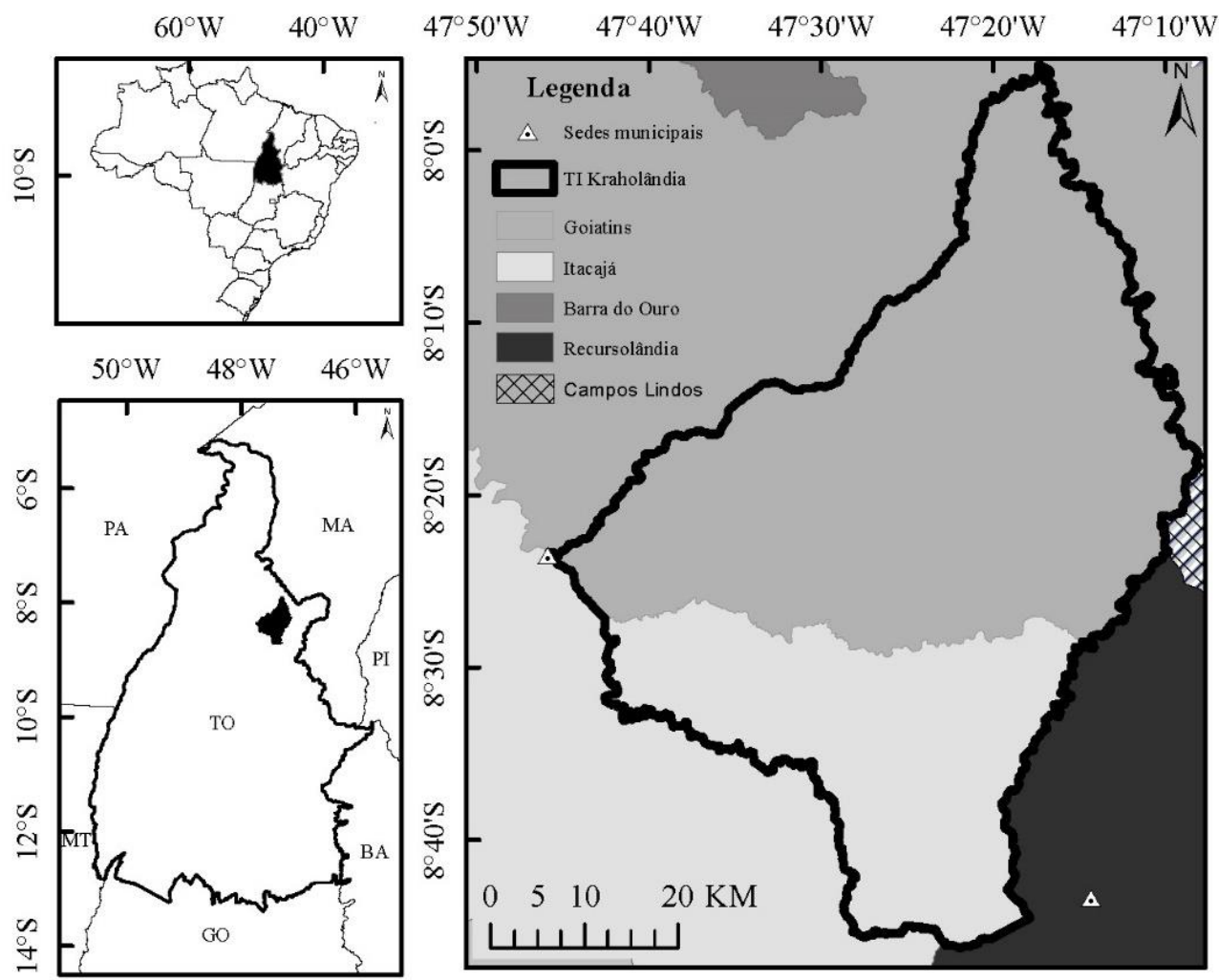

Figure 1. Location of Kraolândia indigenuos land.

Figura 1. Localização da TI Kraolândia.

\section{Burned area}

Areas affected by burnings and forest fires, between 2003 and 2014, were delimited starting from satellite images. Products of four distinct sensors were used (LANDSAT 5, CBERS 2, Resoursat-1 and LANDSAT 8) to ensure complete temporal and spatial coverage of the study area, totalizing 23 scenes, where months from June to September were prioritized being the period with the greatest fire occurrence. Eventually, in case of great cloud presence, images from October, November and December were used.

To detect burnings and forest fires scars, a methodology similar to the one of Daldegan et al. (2014) was implemented, using the algorithm of Mahalanobis. Every satellite image suffers from radiometric errors interference and radiometric correction is a tool used to correct this negative effect. To obtain the radiometric correction, the following information from LANDSAT were used: month, year and day of image acquisition, sun elevation degree, maximum and minimum calibration limits of each band.

Methodologic execution followed the following steps: a) download of images bands; b) radiometric correction of bands in each scene; c) composition of raster images with all bands of the same scene; d) geo-referencing of images basing on LANDSAT 8 images; e) definition of the 05 regions of interest (ROI) of each image, with seven samples per each ROI; f) supervised classification of ROIs with Mahalanobis algorithm; g) manual demarcation of areas reached by burnings/fires (inclusion of not detected areas); creation of the burnings scares vector per year; i) union of vectors in a single one; and $\mathrm{j}$ ) individualization of calculation of the annually burned area (Figure 2). 


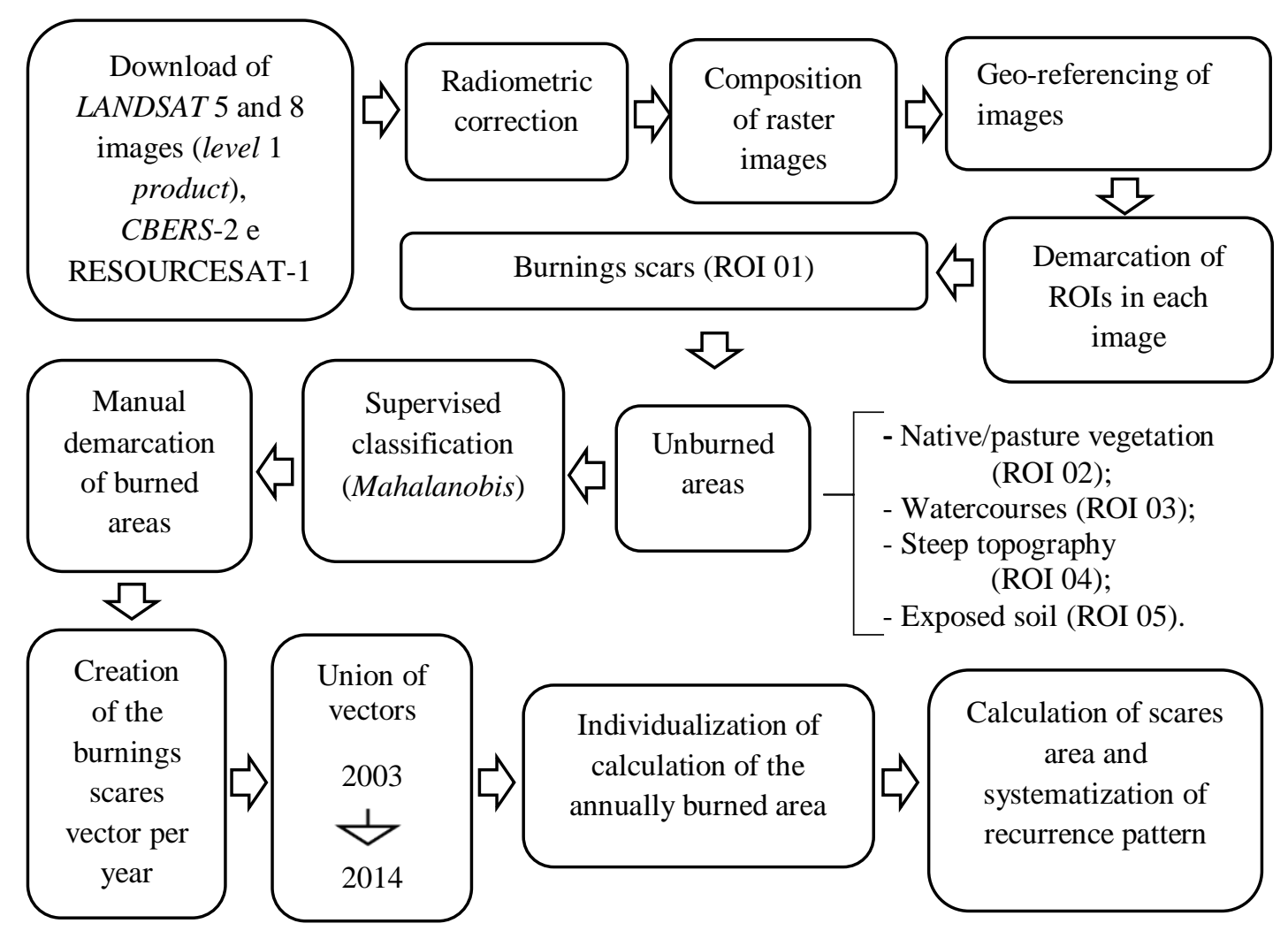

Figure 2. Methodological flowchart.

Figura 2. Fluxograma metodológico.

Demarcation of ROIs consists in delimiting the areas of interest by a vector. In the present work, five types of ROIs were used in each image, which differentiated the burned areas (ROI 01) from unburned areas (ROIs from 02 to 05). Each ROI was represented by at least five vectors in different positions of each image.

\section{Recurrence of the burned areas}

Recurrence map was created by overlapping vectors from 2003 to 2014, which were individualized. Each polygon corresponds to a line in the attribute table. Each vector contains 12 columns representing the year (2003 to 2014), where in case of fire the value " 1 " is in the field corresponding to the year and the value " 0 " appears when there was no fire occurrence in the area. Recurrence patterns were obtained nominally extracting the sequential intervals of the table and then grouping them. With this nomenclature, it is intended that the represented polygon had its area burned in the year 2003 (year 1), going through a 9 years period with no fires, with the first recurrence in 2013 , followed by a new recurrence in 2014.

The sum of all fire occurrences along the studied period is given by the formula:

$$
q=\sum_{i=1}^{n} i
$$

where: $\mathrm{i}=$ year; $\mathrm{q}=$ number of times the area was entirely burned; rec $=\mathrm{q}-1$, where rec $=$ number of recurrences. the equation:

Total burned area along the 12 years period by frequency of occurrence $\left(\mathrm{A}_{\mathrm{q} 12}\right)$, was calculated by

$$
A_{q 12}=q \times A_{q} \times P_{a} \text {, }
$$


where: $\mathrm{A}_{\mathrm{q} 12}=$ total burned area along the 12 years period by frequency of occurrence; $\mathrm{A}_{\mathrm{q}}=$ annually burned area in the desired frequency of occurrence; $\mathrm{P}_{\mathrm{a}}=$ total survey period in years $=12$ years.

The average burning frequency in months $\left(\mathrm{FMQ}_{\mathrm{m}}\right)$ represents the average interval of burnings/fires along the entire studied period. It was obtained by the equation:

$$
\mathrm{FMQ}_{\mathrm{m}}=\mathrm{P}_{\mathrm{m}} / \mathrm{q} \text {, }
$$

where: $\mathrm{FMQ}_{\mathrm{m}}=$ average frequency of burnings in months; $\mathrm{P}_{\mathrm{m}}=$ total survey period in months $=144$ months; $\mathrm{q}=$ number of times in which the area was completely burned.

\section{Growth rate}

Growth rates were obtained through the following equation:

$$
\operatorname{Tx}(\%)=\left(\text { Year }_{\mathrm{n}} / \text { Year }_{\mathrm{n}-1}\right) \times 100
$$

\section{Hotspots}

The National Institute of Space Research (Instituto Nacional de Pesquisas Espaciais) (INPE), provides daily data on hotspots from various polar and geostationary satellites. These data are generated collecting data from sensors, which operate in bands from $3.7 \mu \mathrm{m}$ e $4.1 \mu \mathrm{m}$. In general, burnings with minimum dimension of $30 \times 1 \mathrm{~m}$ are captured and classified as hotspots, almost in real time. Burnings with at least $900 \mathrm{~m}^{2}$ can be detected with the AVHRR sensor (ATUNES, 2000).

To compare the relation burned-area/hotspots, satellites with optical sensors operating in the medium thermal-band of $4 \mu \mathrm{m}$ were used, received by INPE from various satellites. These satellites were NOAA-15, NOAA-16, NOAA-18 and NOAA-19, TERRA, ACQUA, GOES-12, GOES-13 and MSG-2. Data of hotspots registered in Tocantins between 01/01/2003 and 07/11/2014 were used, being provided by the Images Processing Division (DPI) of INPE.

\section{RESULTS}

\section{Dimensions of the burned area}

Figure 3 presents the evolution of burned areas over time in the TI Krahôlandia.

The sum of the total burned area in 12 years was 1,516,872.51 ha, representing 4.94 times the extension of TI Krahôlandia (306,871.02 ha). Average annual burned area was 126,406.04 ha, corresponding to $41.1 \%$ of the TI (Table 1 ).

Table 1. History of burned and unburned areas in the Krahôlandia indigenous land.

\begin{tabular}{|c|c|c|c|c|c|c|c|c|c|}
\hline \multirow{2}{*}{ Year } & \multicolumn{3}{|c|}{ Burned area } & \multicolumn{3}{|c|}{ Unburned area } & \multicolumn{3}{|c|}{$\begin{array}{c}\text { Interval of } \\
\text { standard } \\
\text { deviation }\end{array}$} \\
\hline & $\begin{array}{c}\text { Annual } \\
\text { (ha) }\end{array}$ & $\begin{array}{c}\text { Percentage } \\
\text { of TI }(\%)\end{array}$ & $\begin{array}{c}\text { Percentage } \\
\text { of burned } \\
\text { area }^{1}(\%)\end{array}$ & $\begin{array}{c}\text { Annual } \\
\text { (ha) }\end{array}$ & $\begin{array}{c}\text { Percentage of } \\
\text { TI }(\%)\end{array}$ & $\begin{array}{l}\text { Percentage } \\
\text { of burned } \\
\text { area }^{2}(\%)\end{array}$ & $\overline{1}$ & $\mathbf{0}$ & 1 \\
\hline 2003 & $81,707.77$ & 26.6 & 5.4 & $225,163.26$ & 73.4 & 10.4 & $\mathrm{X}$ & & \\
\hline 2004 & $112,437.49$ & 36.6 & 7.4 & $194,433.54$ & 63.4 & 9.0 & & $\mathrm{X}$ & \\
\hline 2005 & $162,922.73$ & 53.1 & 10.7 & $143,948.30$ & 46.9 & 6.6 & & & $\mathrm{X}$ \\
\hline 2006 & $71,764.89$ & 23.4 & 4.7 & $235,106.13$ & 76.6 & 10.9 & $\mathrm{X}$ & & \\
\hline 2007 & $185,297.86$ & 60.4 & 12.2 & $121,573.17$ & 39.6 & 5.6 & & & $\mathrm{X}$ \\
\hline 2008 & $83,484.87$ & 27.2 & 5.5 & $223,386.15$ & 72.8 & 10.3 & $\mathrm{X}$ & & \\
\hline 2009 & $72,960.89$ & 23.8 & 4.8 & $233,910.14$ & 76.2 & 10.8 & $\mathrm{X}$ & & \\
\hline 2010 & $165,503.46$ & 53.9 & 10.9 & $141,367.57$ & 46.1 & 6.5 & & & $\mathrm{X}$ \\
\hline 2011 & $146,493.10$ & 47.7 & 9.7 & $160,377.92$ & 52.3 & 7.4 & & $\mathrm{X}$ & \\
\hline 2012 & $179,993.36$ & 58.7 & 11.9 & $126,877.66$ & 41.3 & 5.9 & & & $\mathrm{X}$ \\
\hline 2013 & $99,556.55$ & 32.4 & 6.6 & $207,314.47$ & 67.6 & 9.6 & $X$ & & \\
\hline 2014 & $154,749.54$ & 50.4 & 10.2 & $152,121.49$ & 49.6 & 7.0 & & $\mathrm{X}$ & \\
\hline Total & $1,516,872.51$ & & & $2,165,579.78$ & & & & & \\
\hline
\end{tabular}

Tabela 1. Histórico das áreas queimadas e não-queimadas na TI Krahôlandia.

${ }^{1}$ Refers to the total burned area over the twelve years of the study period; ${ }^{2}$ Refers to the total burned area over the twelve years of the study period

FLORESTA, Curitiba, PR, v. 45, n. 4, p. 853 - 864, out. / dez. 2015.

Oliveira, L. N. de. et al.

ISSN eletrônico 1982-4688 / ISSN impresso 0015-3826 
There was significant annual variation in the dimensions of the burned area, varying from 71.764 ha (2006) to 185.297 (2007). In this perspective, years 2004, 2011 and 2014 were within the average standard deviation representing, respectively, 36.6, 47.7 and $50.4 \%$ of the TI extension. Years 2003, 2006, 2008, 2009 and 2013, had a standard deviation lower than the average, with burned areas representing respectively $26.6,23.4,27.2,23.8$ and $32.4 \%$ of the TI area. Years with deviation above the average were 2005 (53.1\% of TI), 2007 (60.4\%), 2010 (53.9\%) and 2012 (58.7\%) (Table 1).

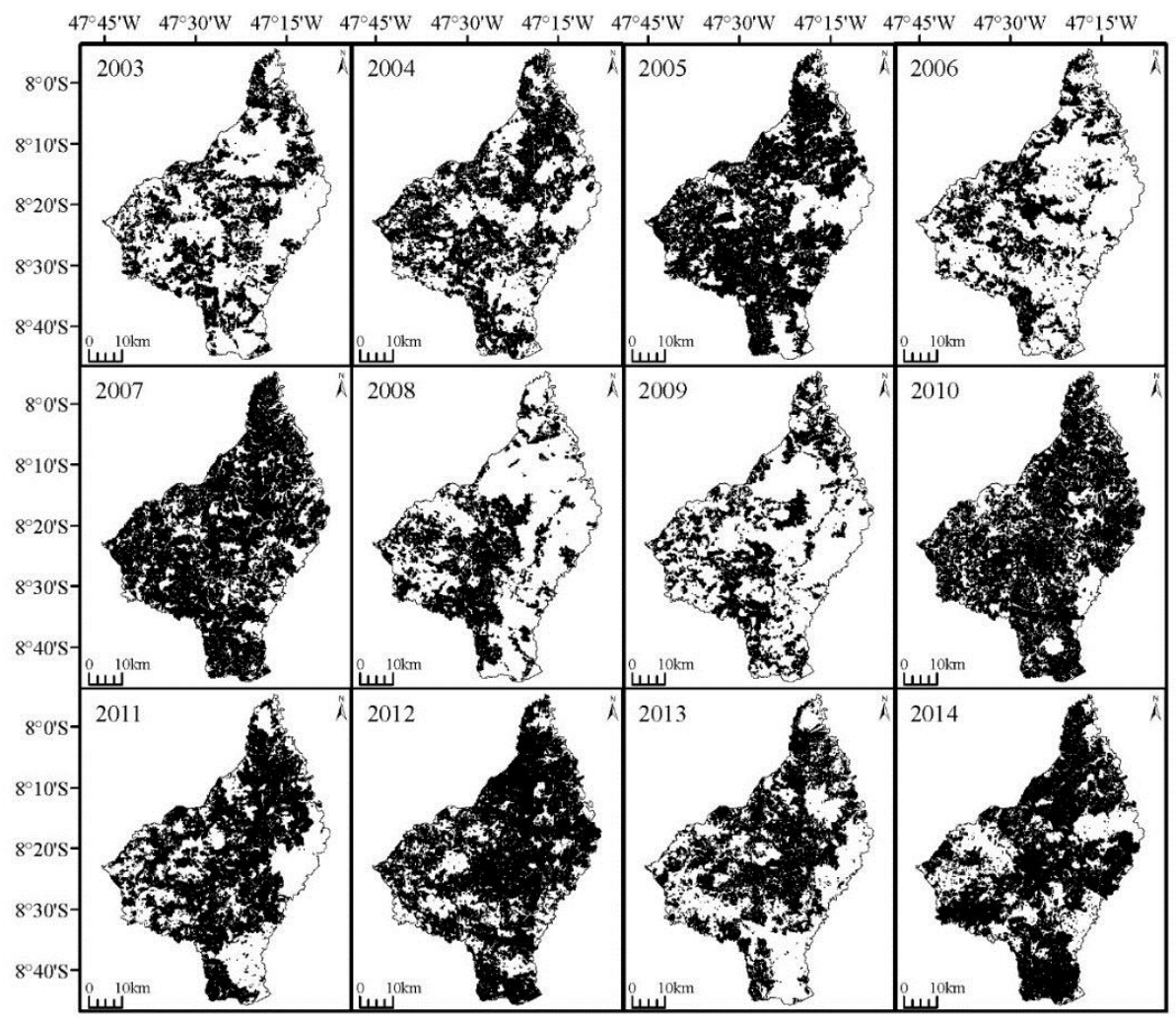

Figure 3. Burned area map on Krahôlandia indigenous land 2003 to 2014.

Figura 3. Mapa de área queimada na TI Krahôlandia de 2003 a 2014.

Analyzing the years of 2003/2004; 2004/2005; 2006/2007; 2009/2010; 2011/2012; 2013/2014 there was an average growth rate of the burned areas and forest fires around $1.78 \%$, varying from 1.23 to $2.78 \%$ (figure 4). This growth rate was followed by percentage of hotspots of the reference satellite and of all the other satellites.

Growth rates of burned areas and hotspots had similar behavior, showing that during the studied period, growth and decrease rates of the burned areas could be represented by hotspots. However, hotspots positive rates, except in the period 2009/2010, had a small deviation, underestimating the burned area growth rate. When there was reduction of the burned areas compared to the previous year (negative rate), decrease rates of hotspots gave overestimation of values. This is confirmed with the analysis of the standard deviation in relation with the burned area, as one can observe in table 2.

\section{Distribution of the burned area}

The greatest recurrence of burned areas in TI Krahôlandia was concentrated in the northern, central and southwestern portions (Figure 5).

The reports of burnings and forest fires occurrences were grouped into classes. Class " 0 "indicates that there were no fires over the 12 years. Class 2 represents all the polygons with 2 burnings/fires over the 
studied period. The second column of table 3 describes the number of historic recurrences of burnings/fires of the class.

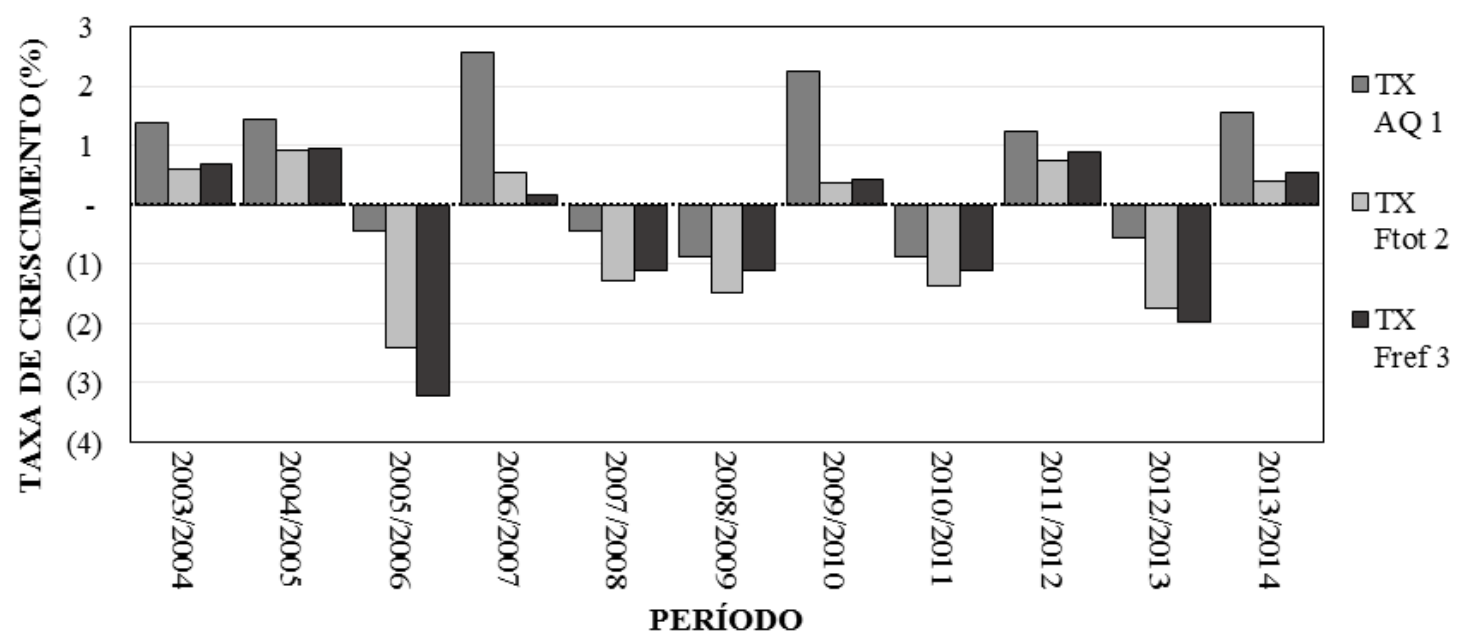

Figure 4. Evolution of growth rates of the burned areas and hotspots in Krahôlandia indigenous land.

Figura 4. Evolução das taxas de crescimento das áreas queimadas e dos focos de calor na TI Krahôlandia ${ }^{1} \mathrm{TX}$ AQ: taxa de crescimento da área queimada; ${ }^{2} \mathrm{TX} \mathrm{F}_{\text {to: }}$ taxa de crescimento dos focos de calor (todos os satélites); ${ }^{3} \mathrm{TX} \mathrm{F}_{\mathrm{ref}}$ : taxa de crescimento dos focos de calor do satélite de referência).

${ }^{1} \mathrm{TX}$ AQ: growth rate of the burned area; ${ }^{2} \mathrm{TX} \mathrm{F}_{\text {tot }}$ growth rate of hotspots (all satellites); ${ }^{3} \mathrm{TX} \mathrm{F}_{\mathrm{ref}}$ : growth rate of hotspots (reference satellite).

Table 2. Standard deviation of the analysis of growth rates of the burned areas in relation to hotspots.

Tabela 2. Análise do desvio padrão das taxas de crescimento das áreas queimadas em relação aos focos de calor.

\begin{tabular}{|c|c|c|c|c|c|c|c|c|c|c|}
\hline \multirow[t]{2}{*}{ Period } & \multirow[t]{2}{*}{$\mathbf{T X}_{\mathrm{Ftot}}{ }^{2}$} & \multirow[t]{2}{*}{$\mathrm{TX}_{\mathrm{AQ}}{ }^{1}$} & \multicolumn{3}{|c|}{$\begin{array}{c}\text { Standard deviation } \\
\text { interval }\left(\mathrm{TX}_{\mathrm{Ftot}}^{2} \mathrm{e}\right. \\
\left.\mathrm{TX}_{\mathrm{AQ}}{ }^{1}\right) \\
\end{array}$} & \multirow[t]{2}{*}{$\mathbf{T X}_{\text {Fref }}{ }^{3}$} & \multirow[t]{2}{*}{$\mathrm{TX}_{\mathrm{AQ}}{ }^{1}$} & \multicolumn{3}{|c|}{$\begin{array}{c}\text { Standard deviation } \\
\text { interval }\left(\mathrm{TX}_{\mathrm{Fref}}{ }^{3} \mathrm{e}\right. \\
\left.\mathrm{TX}_{\mathrm{AO}}{ }^{1}\right)\end{array}$} \\
\hline & & & -1 & $\mathbf{0}$ & 1 & & & -1 & 0 & 1 \\
\hline $2003 / 2004$ & 0.6 & 0.7 & $\mathrm{X}$ & & & 0.7 & 0.7 & $\mathrm{X}$ & & \\
\hline $2004 / 2005$ & 0.9 & 0.7 & & & $\mathrm{X}$ & 1.0 & 0.7 & & & $\mathrm{X}$ \\
\hline $2005 / 2006$ & -2.4 & -2.3 & $\mathrm{X}$ & & & -3.2 & -2.3 & $\mathrm{X}$ & & \\
\hline $2006 / 2007$ & 0.5 & 0.4 & & & $\mathrm{X}$ & 0.2 & 0.4 & $\mathrm{X}$ & & \\
\hline $2007 / 2008$ & -1.3 & -2.2 & $\mathrm{X}$ & & & -1.1 & -2.2 & & & $\mathrm{X}$ \\
\hline 2008/2009 & -1.5 & -1.1 & $\mathrm{X}$ & & & -1.1 & -1.1 & & & $\mathrm{X}$ \\
\hline $2009 / 2010$ & 0.4 & 0.4 & $\mathrm{X}$ & & & 0.4 & 0.4 & & $\mathrm{X}$ & \\
\hline $2010 / 2011$ & -1.4 & -1.1 & $\mathrm{X}$ & & & -1.1 & -1.1 & & & $\mathrm{X}$ \\
\hline $2011 / 2012$ & 0.7 & 0.8 & $\mathrm{X}$ & & & 0.9 & 0.8 & & & $\mathrm{X}$ \\
\hline $2012 / 2013$ & -1.7 & -1.8 & & & $\mathrm{X}$ & -2.0 & -1.8 & X & & \\
\hline $2013 / 2014$ & 0.4 & 0.6 & $X$ & & & 0.5 & 0.6 & $\mathrm{X}$ & & \\
\hline
\end{tabular}

${ }^{1} \mathrm{TX}_{\mathrm{AQ}}$ : taxa de crescimento de área queimada; ${ }^{2} \mathrm{TX}_{\mathrm{Ftot}}$ taxa de crescimento dos focos de calor de todos os satélites; ${ }^{3} \mathrm{TX}_{\mathrm{Fref}}:$ taxa de crescimento dos focos de calor do satélite de referência). ${ }^{1} \mathrm{TX}_{\mathrm{AQ}}$ : growth rate of the burned area; ${ }^{2} \mathrm{TX}_{\mathrm{Ftot}}$ : growth rate of hotspots of all satellites; ${ }^{3} \mathrm{TX}$ Fref: growth rate of hotspots (reference satellite).

Comparing the areas of each class of burnings/fires occurrence, the one with the greatest value was the class with 5 occurrences, with $12.2 \%$, followed by 4.6 and 7 recurrences, with $11.7,11.5$ and $10.8 \%$, respectively (Table 3). These occurrences represent $46.2 \%$ of the TI area. 


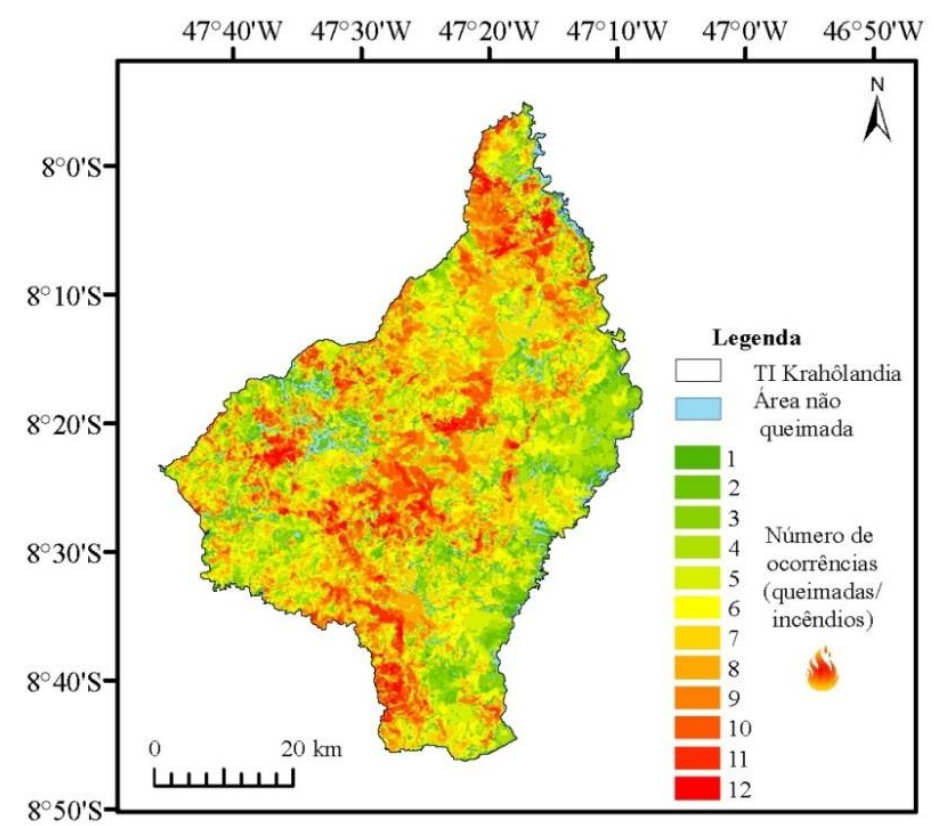

Figure 5. Incidence of burned areas and forest fires in Krahôlandia indigenous land.

Figura 5. Mapa de incidência de áreas queimadas e incêndios florestais na TI Kraholândia.

Table 3. Distribution of burned areas / recurrence during the study period.

Tabela 3. Distribuição das áreas queimadas/recorrências durante o período de estudo.

\begin{tabular}{lccccc}
\hline $\begin{array}{l}\mathbf{N}^{\circ} \text { of } \\
\text { burnings/fires }\end{array}$ & $\begin{array}{c}\text { Number of } \\
\text { recurrences }\end{array}$ & $\begin{array}{c}\text { Area } \\
\text { (ha) }\end{array}$ & $\begin{array}{c}\text { Number of } \\
\text { polygons }\end{array}$ & $\begin{array}{c}\text { Percentageof the } \\
\text { total TI area(\%) }\end{array}$ & $\begin{array}{c}\text { Average frequency } \\
\text { of burnings in } \\
\text { months }\end{array}$ \\
\hline 0 & - & $29,764.47$ & 2,290 & 9.7 & - \\
1 & - & $19,102.10$ & 27,175 & 6.2 & 72 \\
2 & 1 & $21,284.93$ & 49,430 & 6.9 & 48 \\
3 & 2 & $29,320.25$ & 65,623 & 9.6 & $\mathbf{3 6}$ \\
$\mathbf{4}$ & $\mathbf{3}$ & $\mathbf{3 5 , 9 8 8 . 0 6}$ & $\mathbf{7 4 , 9 6 4}$ & $\mathbf{1 1 . 7}$ & $\mathbf{2 8 . 8}$ \\
$\mathbf{5}$ & $\mathbf{4}$ & $\mathbf{3 7 , 5 2 8 . 0 4}$ & $\mathbf{7 5 , 8 2 7}$ & $\mathbf{1 2 . 2}$ & $\mathbf{2 4}$ \\
$\mathbf{6}$ & $\mathbf{5}$ & $\mathbf{3 5 , 2 2 3 . 3 3}$ & $\mathbf{6 8 , 5 3 4}$ & $\mathbf{1 1 . 5}$ & 18.0 \\
$\mathbf{7}$ & $\mathbf{6}$ & $\mathbf{3 3 , 0 3 6 . 4 5}$ & $\mathbf{5 4 , 9 2 3}$ & $\mathbf{1 0 . 8}$ & 16.0 \\
8 & 7 & $26,872.64$ & 38,576 & 8.8 & 14.4 \\
9 & 8 & $18,641.16$ & 23,017 & 6.1 & 13.1 \\
10 & 9 & $12,597.85$ & 10,698 & 4.1 & 12 \\
11 & 10 & $5,818.84$ & 3,369 & 1.9 & - \\
\hline
\end{tabular}

However, analyzing the impact of these events over the 12 years of the study period $\left(\mathrm{A}_{\mathrm{q} 12}\right)$, in terms of size of the burned area, appears that the occurrences causing the greatest burned areas were classes with frequency of occurrence 7, 8,6 and 5. Together, these classes were responsible for a burned area of $845,186.42$ ha, which corresponds to $55.72 \%$ of the total burned area in the period.

\section{Systemic occurrence in frequency patterns of the burned areas}

One could also observe the great diversity of frequency patterns in the burned area, where the 494,859 resulting polygons from the overlapping process of burned areas over the 12 studied years, gave 4.093 frequency patterns of burned areas of the 4096 probabilistically possible patterns. The most unusual frequency pattern was where there were 9 years without burnings. These patterns represent an area of $55,647.04 \mathrm{ha}$, in other words only $18.1 \%$ of the entire burned area. 
Making the selection of polygons that suffered overtime the same interval between frequencies of burnings, one can observe that they represent only $6,725.12$ ha of the area. This value represent $2.2 \%$ of the total burned area in TI Krahôlandia (Table 4).

Table 4. Areas with regular recurrences in Krahôlandia indigenous land. (2003-2014).

Tabela 4. Áreas com recorrências regulares na TI Krahôlandia (2003-2014).

\begin{tabular}{lccc}
\hline $\begin{array}{l}\text { Frequency of } \\
\text { occurrence }\end{array}$ & Total area $($ ha) & $\begin{array}{c}\text { Percentage of regular } \\
\text { burnings }(\boldsymbol{\%})\end{array}$ & $\begin{array}{c}\text { Percentage of the total TI } \\
\text { area }(\boldsymbol{\%})\end{array}$ \\
\hline Annual & 1692.92 & 25.2 & 0.6 \\
Every 2 years & 235.20 & 3.5 & 0.1 \\
Every 3 years & 310.58 & 4.6 & 0.1 \\
Every 4 years & 202.12 & 3.0 & 0.1 \\
Every 5 years & 2114.29 & 31.4 & 0.7 \\
Every 6 years & 2170.01 & 32.3 & 0.7 \\
\hline Total & 6725.12 & 100 & 2.2 \\
\hline
\end{tabular}

\section{DISCUSSION}

Fire occurrence is natural in Cerrado, however, its high frequency is very harmful for regeneration of various species and might affect the extractive potential of the region (HENRIQUES, 2005). This would damage the communities using the natural resources of Cerrado, like the indigenous populations. In the state of Tocantins, concentration of hotspots in indigenous territories is twice as big as the average of the rest of the state (LAZZARINI et al., 2012), which suggests that some monitoring measures must be taken to evaluate burnings occurrence in these areas.

Hotspots were good indicators to relate increase or decrease of the burned area, but they tend to bias the results, underestimating positive rates and overestimating negative rates. They may contain bias originated from navigation or georeferencing errors (JESUS et al., 2011), or by confusion of radiations generated by bodies of water with radiation reflected from active fires and/or saturation of a complete pixel from a small burned area (PIROMAL et al., 2008). It was already proven that polygons with small $(<10 \mathrm{ha})$ and medium $(<23 \mathrm{ha})$ are difficult to be detected by satellites used by INPE to detect hotspots (TOMZHINSKI et al., 2011). Thus, this kind of data must be used carefully in the evaluation process.

Indigenous lands are mainly protected areas, important for conservation, with native vegetation, occupied and exploited by traditional communities. In the State Park of Jalapão, an integral protection conservation unit located close to TI Krahôlandia, was verified that the sum of burned areas over the 12 years represented almost 4 times its size (PEREIRA JÚNIOR et al., 2014). In TI Krahôlandia, this sum was even bigger ( 5 times its area in the same period). This difference could be explained by the use of fire that natives themselves make for the area management.

Krahô people is divided into two functional groups, named Katamjê and Wakmejê. During the dry season, Wakmejê dedicate to activities related to fire, as locations and timing of burnings, and Katamjê on the other hand lead the activities of plantation (rainy season). This group develops burning activities too, between April to end of September, which are different from the activities determined by the Wakmejê group, basing on individual decisions. The first type of actions is characterized by actions of protection, increase of natural resources, or hunting, while burning actions individually perpetrated have the purpose to help cultivation, collection of honey, cleaning of Cerrado and regeneration of natural pastures (MISTRY et al., 2005). Thus, the form of management adopted by indigenous people may be associated to the greatest extension of the burned area.

However, the type of management applied by this people was not identified in the present study. Within the $41.19 \%$ of the burned indigenous land, there were 4,093 fire occurrence patterns identified. Despite the indigenous community believes that burning of Cerrado should happen every 2 or 3 years (MISTRY et al., 2005), only $0.2 \%$ of the area is in this situation. This demonstrates that the area actually managed is small, or that it is not possible to apply this technique to great extensions.

In the State Park of Jalapão, 77.6\% of the area was affected by fire between 3 and 6 times over the 12 years (PEREIRA JÚNIOR et al., 2014). Values found in TI Krahôlandia were from 4 to 7 times, 
representing $42.2 \%$ of the area. Areas that burned from 3 to 6 times totalized $45 \%$. This result shows that occurrences are more distributed in the TI Krahôlandia.

TI Krahôlandia is surrounded by extensive production farms and monocultures, and is subjected to invasions from alien hunters, fishers and collectors, threatening the food sovereignty of Kraôs people (MISTRY et al., 2005). This might be a factor contributing to the disequilibrium of burnings promoted by the indigenous people, because many forest fires have origin by pyromaniacs, smokers, hunters, fishers, fire balloons and caused by the incorrect use of fire for renovation and cleaning of pastures and culture remains (MEDEIROS, 2002; SANTOS et al., 2006). Meteorological factors cannot be discarded because they may influence the burning regimes too.

An ecologically appropriated management is the one that gives functional maintenance conditions of the ecosystem and the limits of its threat to the ecosystem are depending by adaptations of the species (MYERS, 2006).

\section{CONCLUSIONS}

The present study allows verifying that:

- TI Krahôlandia area cannot be described with a dominant frequency pattern of burnings and forest fires;

- History of fires occurrence is extremely important for management and control of burnings and forest fires, and can be a valuable tool in the Integrated Fire Management (IFM);

- The greatest frequencies of burnings occurrence did not create the greatest burned areas over the studied period.

\section{REFERENCES}

ANTUNES, M. A. H. Uso de satélites para detecção de queimadas e para avaliação do risco de fogo. Ação Ambiental, v. 12, p. 24 - 27, 2000.

CHUVIECO, E.; OPAZO, S.; SIONE, W.; VALLE, H. D.; ANAYA, J.; BELLA, C. D., LIBONATI, R. Global burned-land estimation in Latin America using modis composite data. Ecological Applications, v. 18, n. 1, p. 64 - 79, 2008.

DALDEGAN, G.; CARVALHO, O.; GUIMARÃES, R.; GOMES, R.; RIBEIRO, F.; MCMANUS, C. Spatial patterns of fire recurrence using remote sensing and gis in the brazilian savanna: Serra do Tombador nature reserve, Brazil. Remote Sensing, Basileia, v. 6, n. 10, p. 9873 - 9894, 2014.

FALEIRO, R. M. Resgate do manejo tradicional do Cerrado com fogo para proteção das terras indígenas do oeste do Mato Grosso: um estudo de caso. Biodiversidade Brasileira, Brasília, v. 1, n. 2, p. 86 - 96, 2011.

HARDESTY, J.; MYERS, R.; FULKS, W. Fire, ecosystems and people: a preliminary assessment of fire as a global conservation issue. The George Wright Forum, Hancock, v. 22, n. 4, p. 78 - 87, 2005.

HENRIQUES, R. P. B. Influência da história, solo e fogo na distribuição e dinâmica das fitofisionomias no bioma do Cerrado. In: SCARIOT, A.; SOUSA-SILVA, J. C.; FELFILI, J. M. (Org.). Cerrado: ecologia, biodiversidade e conservação. Brasília: Ministério do Meio Ambiente, 2005, 439 p.

JESUS, S. C.; SETZER, A. W.; MORELLI, F. Validação de focos de queimadas no Cerrado em imagens TM/LANDSAT-5. In: SIMPÓSIO BRASILEIRO DE SENSORIAMENTO REMOTO, 15., 2011, Curitiba. Anais... São José dos Campos: INPE, 2011. p. 8051 - 8058.

LAVALLÉE, D. The first south americans. The peopling of a continent from the earliest evidence to high culture. Salt Lake City: The University of Utah Press, 2000.

LAZZARINI, G. M. J.; FERREIRA, L. C. C.; FELICÍSSIMO, M. F. G.; LIRA, R. G.; JUSTINO, A. G.; GOMES, C. S.; RIBEIRO, J. C. N.; MAGALHÃES, G. R. D. Análise da distribuição de focos de calor no Tocantins entre 2002 e 2011. Interface, Porto Nacional, v. 5, n. 2, p. 24 - 35, 2012.

MEDEIROS, M. B. Manejo de fogo em unidades de conservação do Cerrado. Boletim do Herbário Ezechias Paulo Heringer, Brasília, v. 10, p. 75 - 88, 2002. 
MIRANDA, H. S.; NETO, W. N.; NEVES, B. M. C. Caracterização das queimadas de Cerrado. In: MIRANDA, H. S. (Org.) Efeitos do regime do fogo sobre a estrutura de comunidades de cerrado: resultados do projeto fogo. Brasília-DF: IBAMA, 2010. p. 23 - 33.

MIRANDA, H. S.; BUSTAMANTE, M. M. C.; MIRANDA, A. C. The fire factor. In OLIVEIRA, P. S.; MARQUIS, R. J. (Ed.). The cerrados of Brazil: ecology and natural history of a neotropical savanna. New York: Columbia University Press, 2002.

MISTRY, J.; BERARDI, A.; ANDRADE, V.; KRAHÔ, T.; KRAHÔ, P.; LEONARDOS, O. Indigenous fire management in the Cerrado of Brazil: the case of the Krahô of Tocantins. Human Ecology, v. 33, n 3, p. 365 - 386, 2005.

MYERS, R. L. Convivendo com o fogo: manutenção dos ecossistemas e subsistência com o manejo integrado do fogo. Tallahassee: The Nature Conservancy, 2006. 28 p.

PEREIRA JÚNIOR, A. C.; OLIVEIRA, S. L. J.; PEREIRA, J. M. C.; TURKMAN, M. A. A. Modelling fire frequency in a Cerrado savanna protected area. Plos One, San Francisco-CA, v. 9, n. 7, p. 1 - 11, 2014.

PIROMAL, R. A. S.; RIVERA-LOMBARDI, R. J.; SHIMABUKURO, Y. E.; FORMAGGIO, A. R.; KRUG, T. Utilização de dados MODIS para a deteç̧ão de queimadas na Amazônia. Acta Amazonica, Manaus, v. 38, n. 1, p. 77 - 84, 2008.

PIVELLO, V. R. The use of fire in the Cerrado and Amazonian rainforests of Brazil: past and present. Fire Ecology, v. 7, n. 1, p. 24 - 39, 2011.

RAMBO, A. T. A burning issue: rethinking the transition from hunter-gatherer to industrial sociometabolic regimes. Journal of Industrial Ecology, Yale, v. 19, n. 1, p. 82 - 92, 2014.

RAMOS-NETO, M. B.; PIVELLO, V. R. Lightining fires in a Brazilian savanna national park: rethinking management satrategies. Environmental Management, v. 26, n. 6, p. 675 - 684, 2000.

SANO, E. E.; ROSA, R.; BRITO, J. L. S.; FERREIRA, L. G. Land cover mapping of the tropical savanna region in Brazil. Environmental Monitoring and Assessment, Nova York, v. 166, n. 1 - 4, p. 113 - 114, 2010.

SANTOS, J. F.; SOARES, R. V.; BATISTA, A. C. Perfil dos incêndios florestais no Brasil em áreas protegidas no período de 1998 a 2002. Floresta, Curitiba, v. 36, n. 1, p. 93 - 100, 2006.

TOCANTINS. Secretaria do Planejamento e da Modernização da Gestão Pública. Base de Dados Geográficos do Tocantins - atualização 2012. Palmas: SEPLAN/DZE, 2012. Disponível em: <http://www.seplan.to.gov.br/Portal/governo/geo/bases-vetoriais>. Acesso em: 06/06/2014.

TOMZHINSKI, G. W.; COURA, P. H. F.; FERNANDES, M. D. C. Avaliação da detecção de focos de calor por sensoriamento remoto para o Parque Nacional do Itatiaia. Biodiversidade Brasileira, Brasília, v. 1, n. 2, p. 201 - 211, 2011.

VETTORAZZI, C. A.; FERRAZ, S. F. B. Uso de sistema de informações geográficas aplicados à prevenção e combate a incêndios em fragmentos florestais. Série Técnica IPEF, Piracicaba, v. 12, n. 32, p. $111-115,1998$. 